\title{
FABRICATION OF NANOFIBRES BY ELECTROSPINNING USING KERATIN FROM WASTE CHICKEN FEATHERS, PVA AND AgNPs
}

\section{VARUN DINESH MADAPALLY, PANDIMADEVI M.}

\author{
Department of Biotechnology, School of Bioengineering, SRM Institute of Science and Technology, Kattankulathur
} Email: pandimadevi2008@gmail.com

Received: 17 Apr 2019 Revised and Accepted: 15 Jul 2019

\begin{abstract}
Objective: To prepare and characterise keratin from chicken feathers (CF), collected from the slaughter house, and to blend with poly vinly alcohol (PVA) and biosynthesised silver nanoparticles (AgNPs) and to convert into nanofibers by an elctrospinning process.

Methods: The extraction of keratin from chicken feathers was done by sodium m-bisulphite. The solution was subjected to ammonium sulphate precipitation to separate keratin. The nanoparticles was synthesised using tridax procumbens. The isolated keratin and PVA was mixed in the ration of 50:50 with $1 \mathrm{ml}$ of biosynthesised nanoparticles was blended and made into nanofibres by electrospinning technique.

Results: The precipitated protein was analysed using FT-IR analysis confirming the presence of $\beta$-keratin in the sample isolated from chicken feathers and the concentration of keratin was estimated to be $1.85 \mathrm{~g} / \mathrm{ml}$. PVA solution with $4 \% \mathrm{w} / \mathrm{v}$ had the best film forming ability. The solution containing keratin, PVA and silver nanoparticles was prepared in various proportions. These solutions when subjected to electrospinning, fibrous network was observed in 50:50 (PVA: Keratin) ratio with $1 \mathrm{ml}$ of synthesised silver nanoparticle solution. Hydrogen bonding between keratin and PVA indicated in the XRD analysis showed successful film forming of the nanofiber, the DSC analysis also showed similar results as the obtained peak was at $214{ }^{\circ} \mathrm{C}$ which is in between the characteristic heat degradation temperature of both the keratin and PVA. The thermogravimetric analysis (TGA) showed high thermal stability as the complete degradation of the nanofiber was observed at $420{ }^{\circ} \mathrm{C}$. Incorporation of metal nanoparticles by herbal approach using tridax procumbens in the nanofibers provided the antimicrobial properties. The nanofibres obtained by electrospinning process appeared stable and continous for solutions containing no more than $50 \%$ wt of CF. The average diameter of the nanofibres
\end{abstract} increased as the CF content increased.

Conclusion: Keratin isolated from the waste chicken feathers impregnated with biosyntheised silver nanoparticles using tridax procumbens and PVA can be converted into nanofibers by electrospinning process. Thus, the biocomposite nano fibers are shown as a novel eco-friendly material that must be adequately applied in the development of green composites for the biomedical applications such as wound dressings.

Keywords: Keratin, Chicken feathers, PVA, Tridax procumbens, Nanofibres, Electrospinning

(C) 2019 The Authors. Published by Innovare Academic Sciences Pvt Ltd. This is an open access article under the CC BY license (http://creativecommons.org/licenses/by/4.0/) DOI: http://dx.doi.org/10.22159/ijpps.2019v11i8.33637

\section{INTRODUCTION}

Wound healing is a biological process, where the tissue regeneration of the damaged tissue takes place. Wound healing products are highly in demand due to the increase in population, the patients should be able to recover faster with less trauma. The important factor for the increase in bio-based wound healing products are because of the increasing waste in the environment such as medical waste in the form of gauze, cotton and wound dressings stained with blood, which possess hazardous to the surroundings. This can be avoided using bio-based wound healing products as the products are absorbable and eliminate the need for waste management [1]. Chicken feathers contain over $90 \%$ of protein, mainly $\beta$-keratin, fats and water, which can be utilized for industrial applications [2]. The chicken feathers leads to accumulation, and imparts an important environmental risk to the poultry farming industry and landfills. Keratin is an insoluble protein matrix which forms the feathers, hair, nails, beaks, horn and hooves $[3,4]$. They are known to have a high tensile strength in comparison to all other biological materials and are considered as dead tissues [5]. Keratinous materials exhibit various characteristics such as high stress, water resistant, therefore acts as a diffusion barrier and resists penetration based on their mechanical properties, which are influenced by the disulphide bonds present between two cysteine molecules[6]. It was reported that the feather keratin is a potential source of inexpensive, ecofriendly and commercial biomaterial $[7,8]$. Shindai method to extract the keratin from poultry feathers under reducing conditions were followed by many researchers [9-11].

The soluble keratin have applications in wound healing, healing of burns, cell seeding, cell proliferation, diffusion and in drug. Keratin is extensively used for wound healing as it helps for the increased proliferation of keratinocytes which helps with faster healing of the wounds $[12,13]$. Studies showed that wounds treated with keratinbased product healed $21 \%$ more in $4 \mathrm{~d}$, than wounds treated with the keratin-free product [14]. Developing regenerated keratin fibers could not only provide new sources for biomedical industry to alleviate the fiber shortage, but also add value to poultry industry and address related environmental concerns.

Poly Vinyl Alcohol (PVA) is a water soluble, flexible, non toxic and biodegradable synthetic polymer with film forming properties. It does not impart any harmful side effects and has a high tensile strength, retains water which allows it to form films with embedded substances in its matrix. It easily adheres to surfaces, even in the nano range [15]. Thus, natural polymers are blended into synthetic polymers, the favorable biological functionality is contributed by natural polymers, and the mechanical stiffness is provided by their synthetic counterparts. Such type of hybrid system is expected to significantly improve material properties, by providing a stable, nurturing environment for a broad array of biomedical applications [16]. Tridax Procumbens, is a weed widely available is tropical and subtropical regions. It has pharmacological properties which include antioxidant and anti-inflammatory properties [17], enhanced blood clotting [18], hepatoprotective, wound healing, immunomodulatory, antimicrobial, antiseptic, hypotensive and bradycardiac effect [1922]. Nanoparticles synthesised using chitosan, gelatin beads, conjugated linoleic acid, ricinoleic acid and silver nanoparticle impregnated celulose showed better antimicrobial properties [23]. Electrospinning is a simple and versatile technique to produce micro and nanofibers of polymers, because it provides a potential way to fabricate continuous nanofibers for structural designs [24-26]. The 
nanofibres formed using electrospinning are also highly comfortable due to their ultrafine fibres and used for the wound healing gives a major advantage of matrix structure, which gives an option of incorporating drugs, enzymes and other antimicrobial agents that can help with healing the wound [27].

In the present study, chicken feather (CF) was extracted using sodium m-bisulphite and blended with PVA. And biosynthesised AgNPs from tridax procumbens are incorporated during elctrospinning process. It was expected that the affinity between CF and PVA would facilitate the fibre formation during the spinning process and the AgNPs would facilate the antimicrobial properties to the nanofibres.

\section{Experimental methods}

\section{MATERIALS AND METHODS}

The chicken feathers were obtained from the local chicken shop in Chennai. Ethanol, sodium m-bisulphite (40\% solution), and sodium hydroxide were bought from Himedia and the PVA was bought from Sigma Aldrich. All the chemicals used were of the analytical grade. The plant Tridax Procumbens was collected near SRM Lake and was certified for species identification at Plant anatomy research centre.

\section{Keratin Extraction from chicken feathers}

\section{Pretreatment of chicken feather}

The chicken feather were freshly collected from the market and it was washed repeatedly with water to remove the dirt, blood and dung. The chicken feathers were again soaked in detergent for 1 hour to remove the bad odour, drained and washed thoroughly. The feathers were then soaked in ethanol for $24 \mathrm{~h}$, drained and washed with distilled water. Once the chicken feathers were thoroughly washed, the feathers were spread in the fume hood for about three days and thereafter they were kept in a ventilated oven for $24 \mathrm{~h}$ at $45^{\circ} \mathrm{C}$ to completely remove the moisture. The dried $\mathrm{CF}$ were stored in a desiccator at room temperature, until they were used for the experimental work.

\section{Extraction of keratin from chicken feathers}

In the reduction process, the quill was removed from the feathers and the defatted feathers $(10 \mathrm{~g})$ were put in $250 \mathrm{ml}$ of aqueous solutions containing sodium m-bisulphite and the mixture was shaken at $50{ }^{\circ} \mathrm{C}$ for $2 \mathrm{~h}$. The mixed solution was left in a temperature controlled shaker for $2 \mathrm{~d}$ at $50^{\circ} \mathrm{C}$. The solubilized feather solution is centrifuged at 10,000 rpm for $30 \mathrm{~min}$. The supernatant was used as hair protein extraction and the pellet was recovered, washed with double distilled water and used as an extracted sample [28]. Ammonium sulphate precipitation was carried out to precipitate the crude protein extract. Three concentrations of ammonium sulphate solution such as $80 \%, 90 \%$ and $100 \%$ were prepared using the ammonium precipitation standard chart. For each concentration of ammonium sulphate salt, $30 \mathrm{ml}$ of ice cold distilled water was used with constant stirring at $4{ }^{\circ} \mathrm{C}$. The dissolved ammonium sulphate solution is then added to equal volume of solubilized feather solution in the falcon tubes. The falcon tubes were incubated at $4{ }^{\circ} \mathrm{C}$ overnight and the solution was centrifuged at $10,000 \mathrm{rpm}$ for 20 min. The supernatant was discarded and the pellet was resuspended in $1 \mathrm{ml}$ of distilled water and stored at $4{ }^{\circ} \mathrm{C}$ for further use. The precipitated protein is washed with water several times and then, $2 \mathrm{M}$ sodium hydroxide solution is used to obtain protein back in the solution form. Then it was lyophilized and stored for further use. The protein concentrations were determined by the Bradford assay using bovine serum albumin as the standard. The physical properties of chicken feathers like length, moisture content, density, fineness, fibre strength, elongagtion at break and moisture regain were studies. The chemical action of acid,alkali, solvent, hot and cold water were analysed.

\section{Prepartion of AgNPs}

The leaves and stems of tridax procumbens were thoroughly washed with tape water to remove soil, dirt and finally washed with double distilled water. To prepare the extract, 25 grams of leaves and stems were finely cut and were boiled in $100 \mathrm{ml}$ of deionised water for 15-
$20 \mathrm{~min}$ in a $250 \mathrm{ml}$ of Erlenmeyer flask and the solution were decanted, then filtered using whatmann filter paper No.1 to obtain the extract of definite concentration. $10 \mathrm{ml}$ of extract, which was in

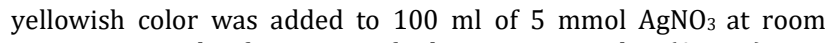
temperature. The formation of silver nanoparticles (AgNPs) was indicated by the development of brown color. The reduction of silver was analysed by UV spectrophotometer within the range of 300-600 nm [29].

\section{Preparation of polymer solutions for electrospinning}

Polymer solution for electrospinning were prepared by dissolving $\mathrm{CF}, \mathrm{PVA}$ and AgNPs at different weight ratios in distilled water. CF powders were dispersed in water and completely dissolved by dropping a $1 \mathrm{mmol} \mathrm{NaOH}$ solution under continous stirring at $45^{\circ} \mathrm{C}$. Different weight ratios of PVA was added to the resulting CF solution and $\mathrm{pH}$ value of mixture was adjusted to 8.5 . The mixtures were mixed vigorously both by manual agitation and vortexing to achieve homogeneous distributions. A series of CF/PVA/AgNps solutions labelled $\mathrm{CF}_{100} / \mathrm{PVA}_{0} / \mathrm{AgNPs}, \mathrm{CF}_{80} / \mathrm{PVA}_{30} / \mathrm{AgNPs}, \mathrm{CF}_{60} / \mathrm{PVA}_{40} / \mathrm{AgNPs}$. $\mathrm{CF}_{50} / \mathrm{PVA}_{50} / \mathrm{AgNPs}, \mathrm{CF}_{40} / \mathrm{PVA}_{60} / \mathrm{AgNPs}, \mathrm{CF}_{20} / \mathrm{PVA}_{80} / \mathrm{AgNPs}$ and $\mathrm{CF}_{0} /$ $\mathrm{PVA}_{100} /$ AgNPs. In all the ratios, $1 \mathrm{ml}$ of AgNPs are maintained throughout.

\section{Electrospinning and stabilizing of CF/PVA/AgNPs}

Keratin/PVA/AgNPs biocomposite film were prepared using different ratios of keratin, PVA and AgNPs. The electrospinning experiments were performed at room temperature. The polymer solution was placed into a $2 \mathrm{ml}$ syringe with a needle having an inner diameter of $0.4 \mathrm{~mm}$. A clamp connected with high voltage power supplier, which can supply positive voltage from 0 to $240 \mathrm{kV}$, was attached to the needle. A rotary collector drum with aluminium foil wounded on it was placed in front of the needle at the distance of $10 \mathrm{~cm}$ from the tip of the needle. The polymer jets were generated from the needle by high voltage field to the collector and formed the nanofiber mesh on the rotating drum. A grounded drum with aluminium foil was placed at a distance of $12 \mathrm{~cm}$ from the capillary tip. The applied voltage and flow rate of the solution were fixed at $20 \mathrm{kV}$ and $0.6 \mathrm{ml} / \mathrm{h}$ flow rate, and $400 \mathrm{rpm}$ drum speed with distance of $12 \mathrm{~cm}$ respectively.

\section{Characterisation of keratin./PVA/AgNPs nanofibres}

\section{Scanning electron microsope (SEM)}

Surface morphology of the bio composite film was visualised by scanning electron microscope. Gold coating was done on bio composites using ion coater 0.1 Torr pressure, $20 \mathrm{~mA}$ current, and 70 s coating time using a $15 \mathrm{kV}$ accelerating voltage.

\section{Fourier transform infra red (FTIR)}

The FTIRspectra of the nanofiber samples were recorded with an infrared spectrometer using Agilent Technologies 6000 series for a wavenumber from 4000 to $650 \mathrm{~cm}^{-1}$ (Ming He et al.,2017).

\section{XRD analysis}

The prepared nanofibers were scraped out of the metal sheet resulting in a powder and given for XRD analysis at SRM University using Thermo Scientific ARL 9900 Pot Flux X-Ray Analyzer.

\section{Differential scanning calorimetry}

To analysis the thermal properties of the prepared nanofiber was performed using differential scanning calorimeter (DSC 4000 System, $100-240 \mathrm{~V} / 50-60 \mathrm{~Hz}$ ) at CATERS, CLRI. The calorimeter cell was flushed with $100 \mathrm{ml} / \mathrm{min}$ nitrogen. The runs were performed on the conditioned samples $\left(24^{\circ} \mathrm{C}, 65 \%\right.$ R. H.) from 30 to $400{ }^{\circ} \mathrm{C}$, at the heating rate of $10^{\circ} \mathrm{C} / \mathrm{min}$.

\section{Thermogravimetric analysis}

TGA analysis using LABSYS evo TGA 1150 at CATERS, CLRI were performed for the prepared nanofibers. The sample was subjected temperature ranging from $25^{\circ} \mathrm{C}$ to $600{ }^{\circ} \mathrm{C}$ at a heating rate of $10^{\circ} \mathrm{C}$ per minute in nitrogen atmosphere. About $3 \mathrm{mg}$ of sample were used in each test using $\mathrm{Al}_{2} \mathrm{O}_{3}$ crucibles. 


\section{Statistical analysis}

The data are shown as mean \pm SEM Differences between experimental results were evaluated according to a one-way analysis of variance (ANOVA), with considered statistically significant. All experiments were performed in triplicate.

\section{RESULTS AND DISCUSSION}

\section{Physico chemical properties of the CF/PVA/AgNps}

The physical properties of the CF was studied. It was found that the length of the feather was $23-37 \mathrm{~mm}$, the moisture content is about $12-13.6 \%$, density is $1.03-1.12 \mathrm{~g} / \mathrm{cc}$, fineness is 3.98 micron, elongation at break $1-5 \%$, moisture gain is $13-13.95 \%$. The chemical properties of the CF wer studied. It was found that the feathers are completely damaged and the weight loss was observed with $1 \mathrm{~N} \mathrm{HCl}$ acid and with $5 \% \mathrm{NaOH}$, the feathers were completely dissolved. The CF was sensitive to solvent and there was a weight loss. In the action of hot water on CF showed less absorbancy and there was also loss in weight.

\section{Keratin from chicken feathers}

The protein content was calculated from the precipitated protein extract and it was found to be $1.64 \mathrm{mg} / \mathrm{ml}$ for $80 \%, 1.41 \mathrm{mg} / \mathrm{ml}$ for $90 \%$ and $1.85 \mathrm{mg} / \mathrm{ml}$ for $100 \%$ ammonium sulphate. The protein content was found to be highest in the case of $100 \%$ ammonium sulphate. The precipated protein was characteristed by FTIR [30].

\section{Agilent Resolutions Pro}

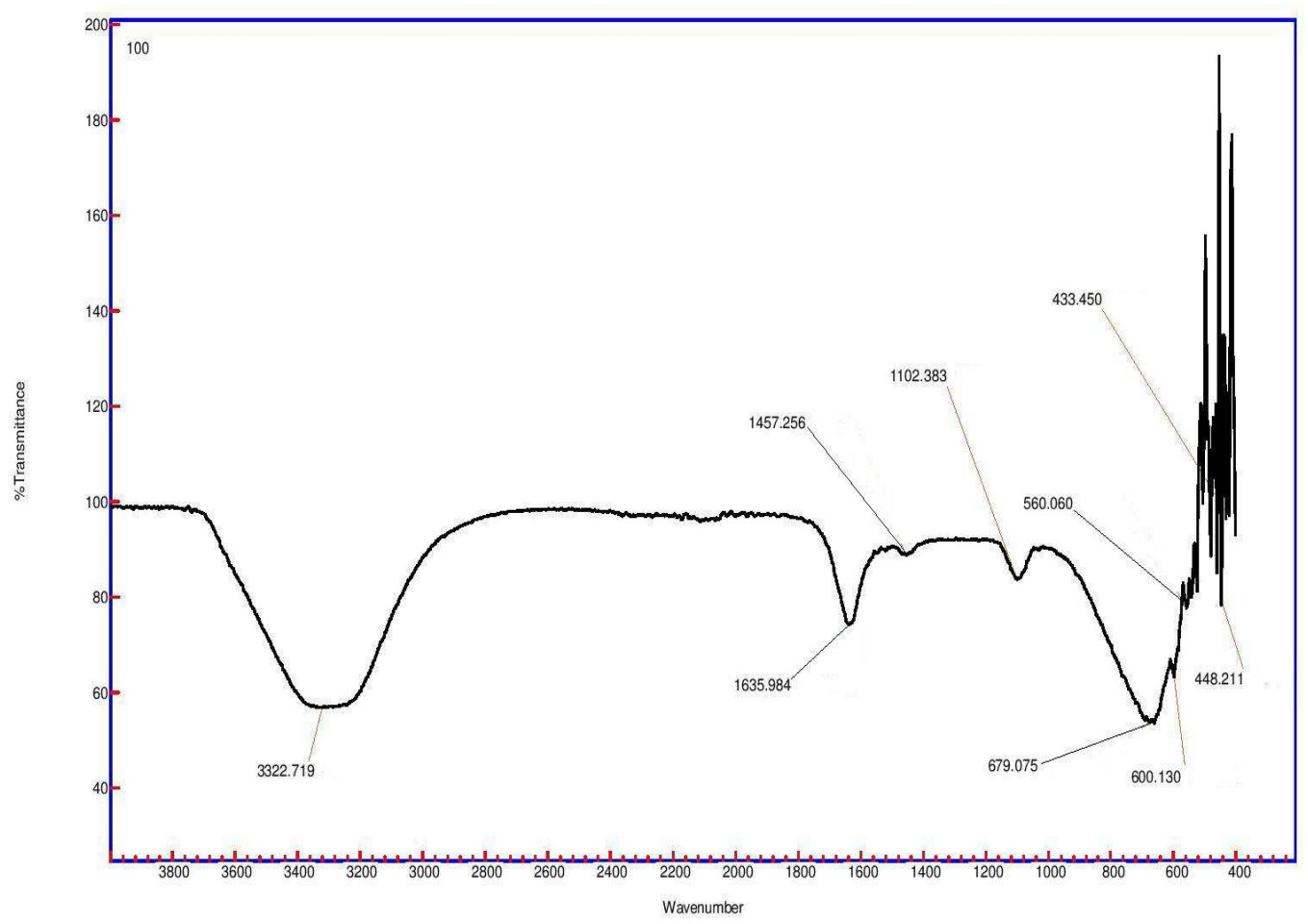

Fig. 1: FTIR analysis of the precipitated protein solution using $100 \%$ saturated solution of ammonium sulphate

The solubilized feather solution precipitated with the $100 \%$ ammonium sulphate concentrations were characterized by FTIR. The FTIR spectra of extracted keratin in the region $400-4000 \mathrm{~cm}^{-1}$ are given in fig. 1, where the characteristic absorption bands are mainly assigned to the peptide bonds (CONH). A broad adsorption band of $\mathrm{CF}$ appearing at $3322 \mathrm{~cm}^{-1}$ is mainly due to hydrogen bonded N-H stretching vibrations, as the peptide $\mathrm{N}-\mathrm{H}$ groups form hydrogen bonds with amide $\mathrm{C}=0$ in the native secondary structure [31]. Amide I band is the most intensely and widely used, among all the amide bands of the backbone peptide groups in the proteins. The amide $\mathrm{I}$ band is connected mainly with the $\mathrm{C}=0$ stretching vibration and it occurs in the range of $1700-1600 \mathrm{~cm}^{-1}$. This band arises mainly from the $\mathrm{C}=0$ stretching vibration of the amide carbonyl group, and it is weakly coupled with the in-plane $\mathrm{N}-\mathrm{H}$ bending and the $\mathrm{C}-\mathrm{N}$ stretching vibration, and it appears in the region between 1700 and $1600 \mathrm{~cm}^{-1}$. It is commonly found in keratin, and the amide showed $\mathrm{C}=0$ stretching vibration within range of $1700-1600 \mathrm{~cm}^{-1}, \mathrm{C}$ $\mathrm{H}$ stretching vibration at $1520 \mathrm{~cm}^{-1}$ and $1220-1300 \mathrm{~cm}^{-1}$ shows $\mathrm{C}-\mathrm{N}$ stretching [32-34]. It has been studied previously that the peaks between $1610-1630 \mathrm{~cm}^{-1}$, which is observed in the FTIR of the protein samples proving the presence of keratin retaining its native structure [35]. It can be seen from fig. 1 that these bands exist in the extracted keratin from the chicken feathers. Thus the product obtained at the end of the extraction confirmed true keratin protein from chicken feathers without the presence of any foreign materials.

\section{XRD analysis of nanofiber}

The X-ray diffraction (XRD) is the most widely used technique for general crystalline material characterization. It is used to measure the average spacing's between layers or rows of atoms, determine the orientation of a single crystal or grain. The \% crystallinity of $\mathrm{CF}$ was found to be 24. This fact is supported by earlier research [36]. From the fig. 2, the appearance of new crystallinity peaks suggesting the formation of other crystalline patterns at a greater angle, e. g. at $2 \theta$ is 24 in the sample that was chemically treated with sodium mbisulphite, is indexed to its strand secondary structure. 


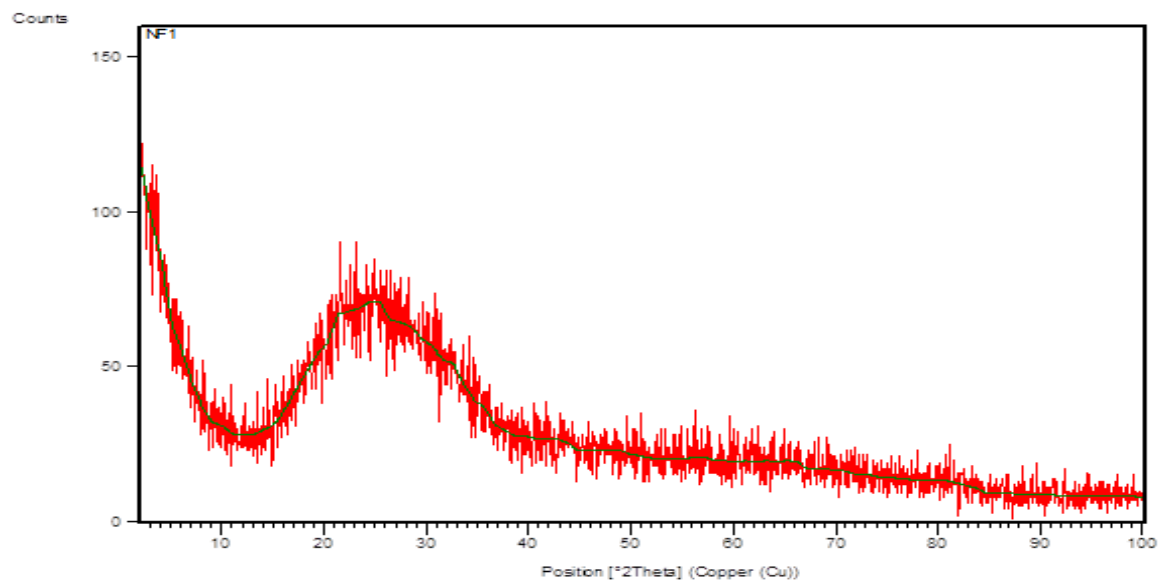

Fig. 2: XRD analysis of electrospun nanofiber containing keratin, PVA, AgNps (50:50)

The nanofiber obtained showed a peak at about $23^{\circ}(2 \theta)$ observed in fig. 2. The crystallinity of the keratin composite nanofibers lies between $22.4 \%$ and $23.5 \%$. The XRD result showed the presence of hydrogen bonding between the PVA and keratin [37].

SEM analysis
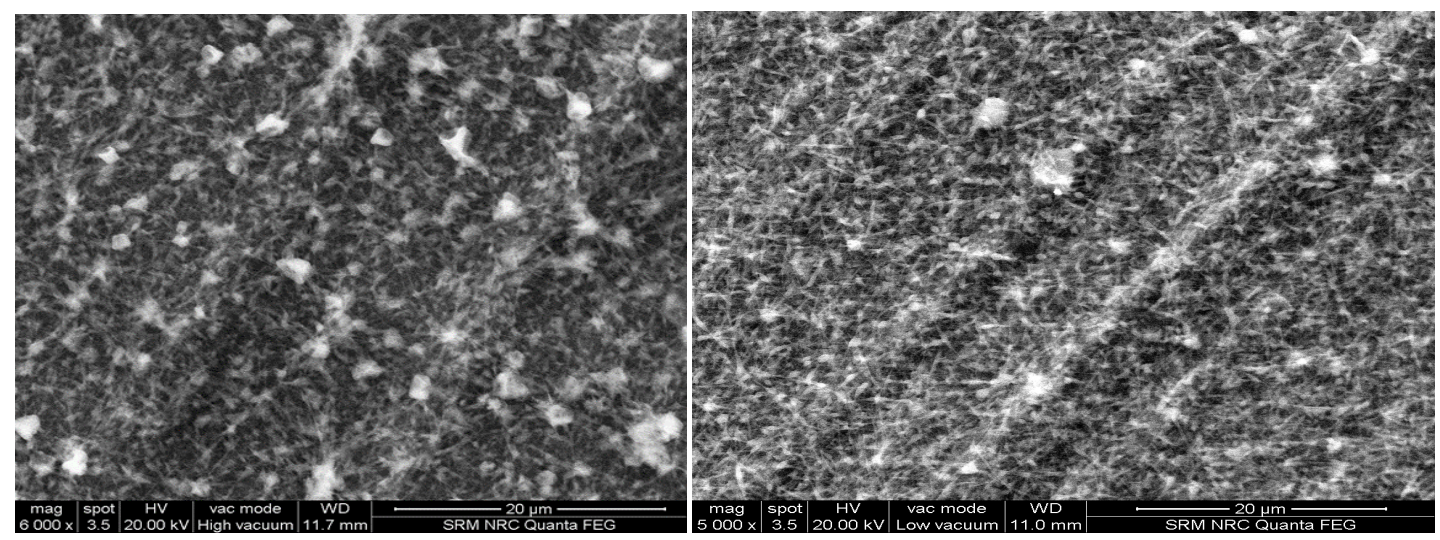

Fig. 3a): SEM image of electrospun nanofiber at the blending ratio of 60:40 of PVA to keratin with silver nanoparticles at magnification of $6000 \mathrm{x}$. 3b) SEM image of electrospun nanofiber at the blending ratio of 40:60 of PVA to keratin with silver nanoparticles at magnification of $6000 \mathrm{x}$
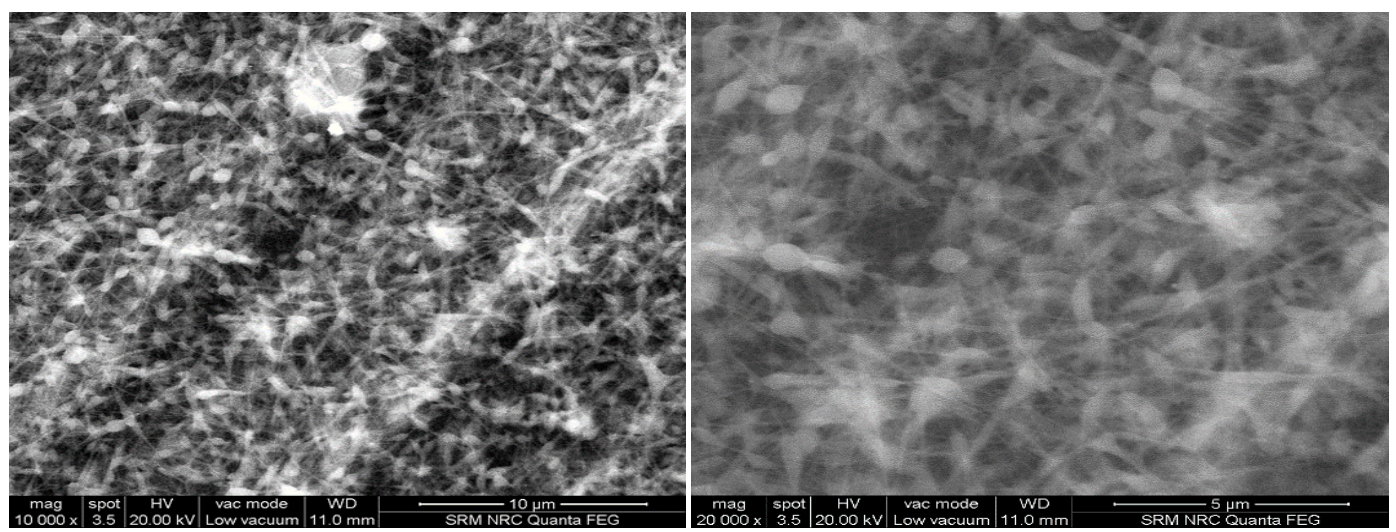

Fig. 3b) and 3 c): SEM image of obtained electrospun nanofiber at the ratio of 50:50 of PVA to keratin with silver nanoparticles (b) at magnification $20000 \times$ (c) at magnification $10000 \times$

Fig. 3a) and fig. 3b) are the SEM images of the electrospun nanofibres in the ratio of 60:40 and 40:60 of keratin and PVA. The nanofibres are obtained were discontinuous film structure and it wasclearly seen in the SEM images. The SEM images of electrospun nanofibers were performed on 50:50 ratio blend, because the rest of the ratios experimented appeared unstable. In the ratio of 90:10 of 
keratin to PVA with $1 \mathrm{ml}$ of silver nanoparticle solution, the nanofibres formation does not take place, because the keratin doesnot possess film forming properties. It was evident that the increase in the ratio of keratin does not form any fibre structure on the electrospinning drum [38]. In the case of increase in the PVA concentration, the nanofibres were straight and uniform. This is mainly due to the film forming properties of PVA. When the CF content was increased further, the electrospinning was not successful [35]. In the case of other ratios, poor morphologies of nanofibres exhibiting many large beads were obtained and the fibres were difficult to handle (data not presented). In a study, it was reported that the fibre structure was not constructed by electrospinning keratin/fibroin blend solutions when the keratin content exceeded 35\% [39]. Similarly, polymer solutions containing no more than $40 \mathrm{wt} \%$ of feather keratin can be elctrospun [35]. The presence of silver nanoparticles are also clearly visible in the figures.
The SEM image of the 50:50 ratio seen in fig. 3a, showed a distinct fibrous matrix structure, stable, smooth bead free, randomly oriented and formed a continuous fiber mat at $20 \mathrm{kV}$ during the electrospinning process,. The SEM image of the 50:50 ratio is seen in fig. $3 \mathrm{a}$ and $3 \mathrm{~b}$, which shows distinct fibrous structure with the silver nanoparticle observed in spherical particles embedded in the fiber matrix. Therefore, the optimum ratio for the nanofiber synthesis is 50:50 of keratin solution to PVA and $1 \mathrm{ml}$ of silver nanoparticle solution [40]. Moreover, the surface of the nanofibers shows heterogeneous microstructures, the surface becomes brighter and also causes roughness, which is the characteristic of increased surface activity of CF. It should be noted that to obtain satisfactory fibres, the ratio of $\mathrm{CF}$ in the blend solution had to be less than or equal to $50 \mathrm{wt} \%$. $\left(\mathrm{CF}_{50} / \mathrm{PVA}_{50}\right)$. Therefore, in the present study, only electrospun fibres from solution containing no more than $50 \mathrm{wt} \%$ of CF were considered.

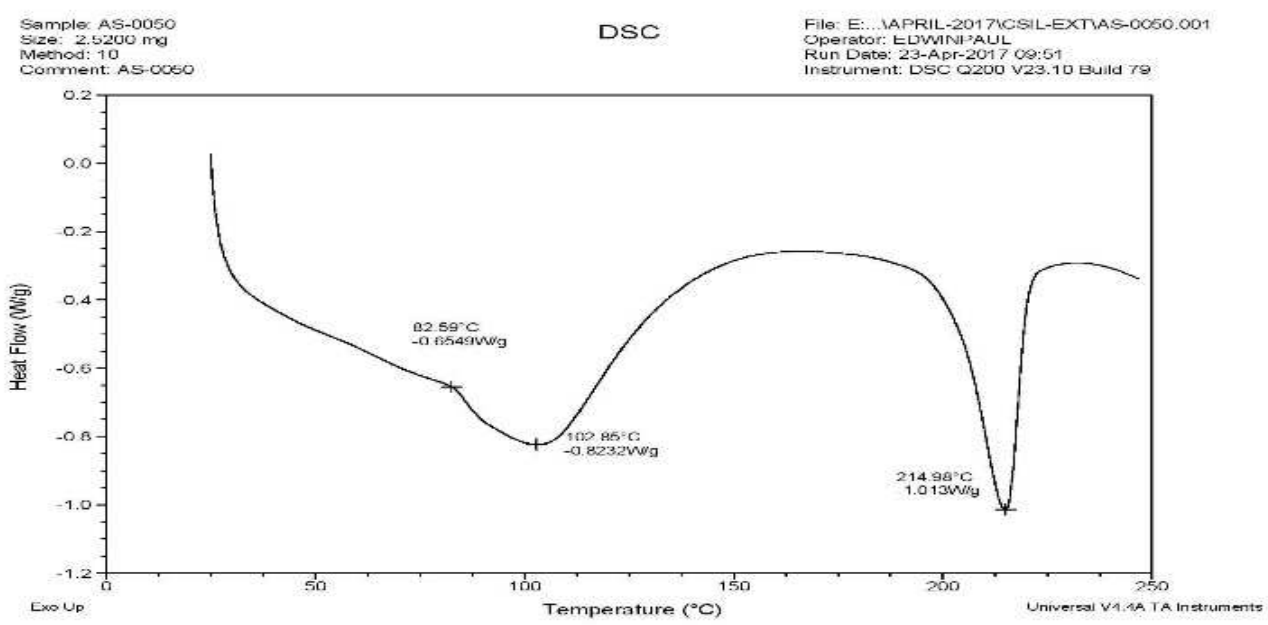

Fig. 4: DSC analysis of electro spun nanofiber containing Keratin, PVA, AgNps (50:50:1)

\section{Differential scanning calorimetry of nanofiber}

The DSC analysis result shown in fig. 4 was obtained and showed a characteristic peak at a temperature of $214{ }^{\circ} \mathrm{C}$. This indicates the formation of hydrogen bonds between keratin and PVA, confirming that single complex was formed correlating to the results obtained by Yao Dou et al.,2015. A low temperature broad peaks below $100{ }^{\circ} \mathrm{C}$ is indicative for the evaporation of residual moisture and denaturation of the protein. It is a distinctively different behavior with broader denaturation. The DSC of CF shows an endothermic peak at $<215^{\circ} \mathrm{C}$, which is usually assigned to $\alpha$-helix disordering and decomposition [41]. The endothermic peak observed at about $215{ }^{\circ} \mathrm{C}$ for the $\mathrm{CF}$ was attributed to the crystalline melting (Tm) of the nanofiber, and the peak area represented the crystallinity of the nanofibers [42]. These observations suggest the loss of $\alpha$-helix structures and gain of amorphous behavior, especially marked with a broadened melting curve trend [43].

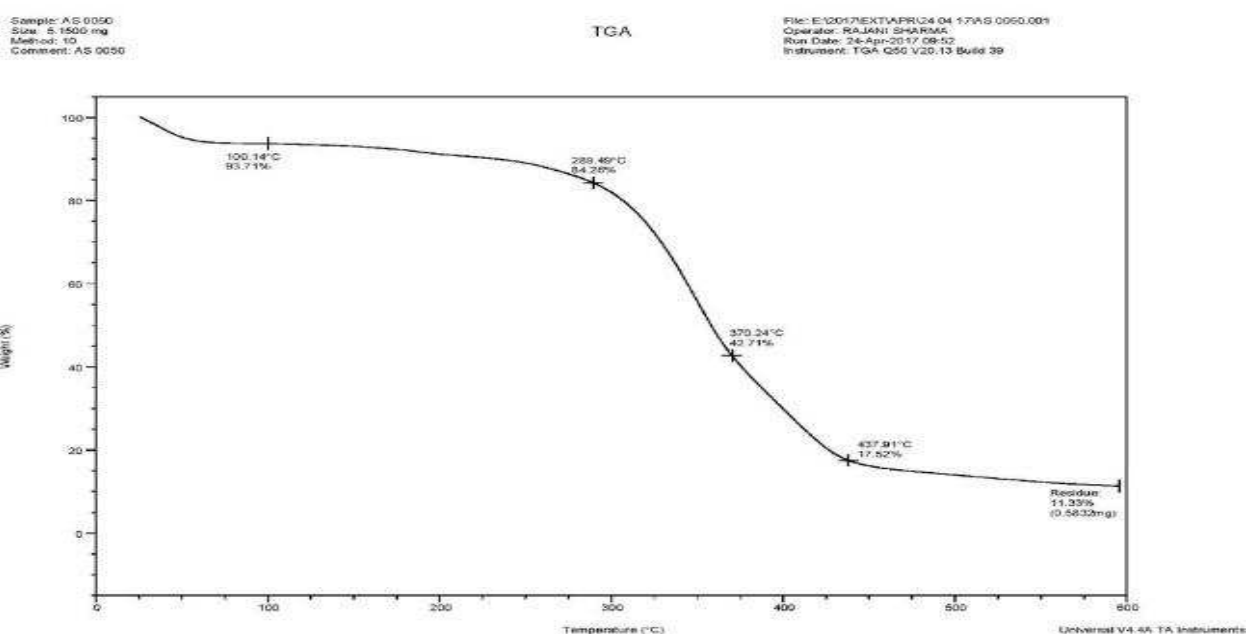

Fig. 5:TGA analysis of electrospun nanofiber containing keratin, PVA, AgNps (50:50:1) 


\section{Thermogravimetric analysis of nanofibre}

The TGA result shown in fig. 5 , shows that the initial weight loss at $100-280^{\square} \mathrm{C}$ is due to moisture loss and weight percentage of the nanofibre reaches its lowest point at $280-420{ }^{\circ} \mathrm{C}$, indi cating that it has a high heat resistance capacity in comparison to the nanofiber formed in earlier studies which had a decreased thermostability [44, 45]. The TGA curves as a function of temperature of the keratin nanofibres showed the decomposition in the temperature range of $280-412{ }^{\circ} \mathrm{C}$. At this juncture, a total weight loss of ca. $90 \%$ was observed. Finally, thermogravimetric analysis showed the higher thermal stability of keratin/PVA nanofibers $\beta$-sheet crystalline structure formed during cast solidification.

\section{CONCLUSION}

In summary, a simple and effective method was developed to obtain novel keratin biomaterials from disused feathers. The antimicrobial properties of synthesised silver nanoparticles provides effective against human pathogens. Incorporation of metal nanoparticles by herbal approach using tridax procumbens in the nanofibers may have persuasive applications in medical therapeutics. Thus, we can conclude that keratin isolated from the waste chicken feathers impregnated with silver nanoparticles and PVA can be converted into nanofibers by electrospinning process. Thus, keratin fibers from chicken feathers are shown as a novel eco-friendly material that must be adequately applied in the development of green composites.

\section{ACKNOWLEDGMENT}

The authors are grateful for the financial support from the SRM Institute of Science and Technology, Kattankulathur.

\section{AUTHORS CONTRIBUTIONS}

All the author have contributed equally

\section{CONFLICT OF INTERESTS}

The authors declared that they have no conflict of interests in this work

\section{REFERENCES}

1. Murtha JL, Ando HY. Synthesis of the cholesteryl ester prodrugs cholesteryl ibuprofen and cholesteryl flufenamate and their formulation into phospholipids microemulsions. J Pharm Sci 1994;83:1222-8.

2. Kumar V, Abbas AK, Fausto N, Aster JC. Tissue renewal, regeneration and repair. In: Robbins, Cotran. editors. Pathologic Basis of Disease. Eighth ed. Philadelphia: Elsevier; 2010. p. 79-110.

3. Teresa KK, Justyna B. Biodegradation of keratin waste: theory and practical aspects. Waste Manage 2011;31:1689-701.

4. Fraser R, MacRae T, Rogers GE. Keratins: their composition, structure, and biosynthesis. Springfield. III: Charles C. Thomas; 1972.

5. Schweizer J, Bowden PE, Coulombe PA, Langbein L, Lane EB, Magin TM, et al. New consensus nomenclature for mammalian keratins. J Cell Biol 2006;174:169-74.

6. Bin Wang, Wen Yang, Joanna McKittrick, Marc Andre Meyers. Keratin: structure, mechanical properties, occurrence in biological organisms, and efforts at bioinspiration. Progress Materials Sci 2016;76:229-318.

7. Fraser RDB, Parry DAD. The structural basis of the filamentmatrix texture in the avian/reptilian group of hard $\beta$-keratins. J Struct Biol 2011;173:391-405.

8. Poole AJ, Church JS, Huson MG. Environmentally sustainable fibers from regenerated protein. Biomacromolecules 2009;11:1-8.

9. Shi Z, Reddy N, Hou XL, Yang YQ. Tensile properties of thermoplastic feather films grafted with different methacrylates. ACS Sustain Chem Eng 2014;2:1849-56.

10. Schrooyen PMM, Dijkstra PJ, Oberthur RC, Bantjes A, Feijen J. Stabilization of solutions of feather keratins by sodium dodecyl sulphate. J Colloid Interf Sci 2001;240:30-9.

11. Moore GR, Martelli SM, Gandolfo C, Sobral PJA, Laurindo JB. Influence of the glycerol concentration on some physical properties of feather keratin films. Food Hydrocolloid 2006;20:975-82.

12. Khosa M, Ullah A. A sustainable role of keratin biopolymer in green chemistry: a review. J Food Processing Beverages 2013;1:8.

13. Priyaah Kumaran, Arun Gupta, Swati Krishna. Synthesis of wound healing keratin hydrogels using chicken feathers proteins and its properties. Int J Pharm Pharm Sci 2017;9:171-8.

14. Cassidy S, Than M. Improved healing of epidermolysis bullosa wounds using a novel keratin gel technology. In: Australian Wound Management Association Conference Proceedings: Darwin, NT, Australia; 2008.

15. Magnus $\mathrm{S}$ Agren. Wound healing biomaterials. Functional biomaterials. Woodhead Publishing series in biomaterials. Elsevier; 2016. p. 2.

16. Tayser Sumer Gaaz, Abu Bakar Sulong, Majid Niaz Akhtar, Abdul Amir H Kadhum, Abu Bakar Mohamad, Ahmed A AlAmiery. Properties and applications of polyvinyl alcohol, halloysite nanotubes and their nanocomposites. Molecules 2015;20:22833-47.

17. Nectow AR, Marra KG, Kaplan DL. Biomaterials for the development of peripheral nerve guidance conduits. Tissue Eng B Rev 2012;18:40-50.

18. Tiwari U, Rastogi B, Singh P, Saraef DK, Vays SP. Immunoregulatory effects of aqueous extract of tridax procumbens in experimental animals. Ethnopharmol 2004;92:113-9.

19. Ikese CO, Okoye ZC, Kukwa DT, Adoga SO, Lenka JL. Effect of aqueous leaf extract of tridax procumbens on blood coagulation. Int J Pharm Sci Res 2015;6:3391-5.

20. Taddei A, Rosas Romero AJ. Bioactivity studies of extracts from tridax procumbens. Phytomedicine 2000; 7:235-41.

21. Himakshi Bhati, Kushwaha, Malik CP. Biosynthesis of silver nanoparticles using fresh extracts of Tridax Procumbens Linn. Indian J Exp Biol 2014;52:359-68.

22. Ravikumar V, Shivashangari K, Devakin T. Hepatoprotective activity of tridaxprocumbens against dgalactosamine/lipopolysaccharide induced hepatitis in rats. Ethnopharmacol 2005;101:55.

23. Salahdeen HM, Yemitan OK, Aladay ARR. Effectof aqueous leaf extract of tridax procumbens on blood pressure and heart rate in rats. Afr J Biomed Res 2004;7:27.

24. Ahmed A Nada, Ahmed G Hassabo, Walid Fayad, Hassan M Awad, Amany A Sleem, Nermeen M Shaffie, et al. Biomaterials based on essential fatty acids and carbohydrates for chronic wounds. J Appl Pharm Sci 2015;3:13-21.

25. Baek HS, Park YH, Ki CS, Park JC, Rah DK. Enhanced chondrogenic responses of articular chondrocytes onto porous silk fibroin scaffolds treated with microwave-induced argon plasma. Surface Coatings Technol 2008;202:5794-7.

26. Yamane S, Iwasaki N, Kasahara Y, Harada K, Majima T, Monde $\mathrm{K}$, et al. Effect of pore size on in vitro cartilage formation using chitosan-based hyaluronic acid hybrid polymer fibers. J Biomed Materials Res Part A 2007;81:586-93.

27. Yamane S, Iwasaki N, Majima T, Funakoshi T, Masuko T, Harada $\mathrm{K}$, et al. IFeasibility of chitosan-based hyaluronic acid hybrid biomaterial for a novel scaffold in cartilage tissue engineering. Biomaterials 2005;26:611-9.

28. Ragetly GR, Slavik GJ, Cunningham BT, Schaeffer DJ, Griffon DJ. Cartilage tissue engineering on fibrous chitosan scaffolds produced by a replica molding technique. J Biomed Materials Res Part A 2010;93A:46-55.

29. Izabela Sinkiewicz, Agata Sliwinska, Hanna Staroszczyk, Ilona Kołodziejska. Alternative methods of preparation of soluble keratin from chicken feathers. Waste Biomass Valorization 2017;8:1043-8.

30. Sangeetha R, Pavithra Niranjan, Dhanalakshmi N. Characterization of silver nanoparticles synthesised using the extract of the leaves of Tridax procumbens. research. J Med Plant 2016;10:159-66.

31. Trabocchi A, Occhiato EG, D Potenza D, Guarna A. Synthesis and conformational analysis of small peptides containing 6-Endo$\mathrm{BT}(\mathrm{t}) \mathrm{L}$ scaffolds as reverse turn mimetics. J Org Chem 2002;67:7483-92. 
32. Wan Ting Sow, Yuan Siang Lui, Kee woel NG. Electrospun human keratin matrices as templates for tissue regeneration. Adv Nanofibers Tissue Eng Regenerative Med 2013;8:531-41.

33. Wojciechowska E, Włochowicz A, Wesełucha Birczyńska A. Application of fourier-transform infrared and Raman spectroscopy to study degradation of the wool fiber keratin. J Mol Struct 1999;511:307-18.

34. Aluigi A, Varesano A, Montarsolo A, Vineis Ferrero, Mazzuchetti G, Tonin C. Electrospinning of keratin/poly(ethylene oxide) blend nanofibers. Wiley Int Sci 2006;104:863-70.

35. Sun P, Liu ZT, Liu ZW. Particles from bird feather: a novel application of an ionic liquid and waste resource. J Hazard Mater 2009;170:786-90.

36. Ming He, Buning Zhang, Yao Doua, Guoqiang Yin, Ying De Cuiac, Xunjun Chenb. Fabrication and characterization of electrospun feather keratin/poly(vinyl alcohol) composite nanofibers. Royal Soc Chem 2017;7:9854-61.

37. Shi Z, Reddy N, Hou XL, Yang YQ. Tensile properties of thermoplastic feather films grafted with different methacrylates. ACS Sustain Chem Eng 2014;2:1849-56.

38. Pavani KV, Gayathramma K, Aparajita Banerjee, Shah Suresh. Photosynthesis of silver nanoparticles using extracts of Itomoea Indica flowers. Am J Nanomaterials 2013;1:5-8.

39. Edwards A, Jarvis D, Hopkins T, Pixley S, Bhattarai N. Poly( $\varepsilon-$ caprolactone)/keratin-based composite nanofibers for biomedical applications. J Biomed Mater Res B Appl Biomater 2015;103B:21-30.

40. Yen KC, Chen CY, Huang JY, Kuo WT, Lin FH. Fabrication of keratin/fibroin membranes by electrospinning for vascular tissue engineering. J Mater Chem B 2016;4:237-44.

41. Wan Ting Sow, Yuan Siang Lui, Kee woel NG. Electrospun human keratin matrices as templates for tissue regeneration. Adv Nanofibers Tissue Eng Regenerative Med 2013;8:531-41.

42. Spei M, Holzem R. Thermoanalytical investigations of extended and annealed keratine. Colloid Polym Sci 1987;265:965.

43. Nakano Y, Bin Y, Bando M, Nakashima T, Okuno T, Kurosu H, et al. Structure and mechanical properties of chitosan/Poly(Vinyl Alcohol) blend films. Macromol Symp 2007;258:63-81.

44. Yao Dou, Buning Zhang, Ming He, Guoqiang Yin, Yingde Cui, Irina N Savina. Keratin/polyvinyl alcohol blend films crosslinked by dialdehyde starch and their potential application for drug release. Polymers 2015;7:580-91.

45. Shuai Li, Xu-Hong Yang. Fabrication and characterization of electrospun wool keratin/poly (vinyl alcohol) blend nanofibers. Adv Materials Sci Eng 2014:7. http:// dx.doi.org/10.1155/2014/163678.

46. Tonin C, Aluigi A, Vineis C, Varesano A, Montarsolo A, Ferrero F. Thermal and structural characterization of poly(ethyleneoxide)/keratin blend films. J Therm Anal Calorimeter 2007;89:601-8. 